\title{
The Relationship Between 8th Grade Turkish Students' Personal Charactertistics, Family Characteristics, Daily Hassles and Their Subjective Well-Being Levels
}

\author{
Serkan Altuntaş ${ }^{1}$, Özcan Sezer ${ }^{1}$ \\ ${ }^{1}$ İnönü University, Turkey \\ Correspondence: İnönü University, Turkey.
}

Received: May 29, $2018 \quad$ Accepted: July $92018 \quad$ Online Published: July 18, 2018

doi:10.11114/jets.v6i8.3319 URL: https://doi.org/10.11114/jets.v6i8.3319

\begin{abstract}
This study investigated whether the subjective well-being of eighth grade students varies with specific individual characteristics, individual circumstances and familial characteristics. The study population was comprised of 408 students (206 girls, 202 boys) who were in the eighth grade in the academic year 2014-2015 in Malatya in Turkey. Data was collected using a 'Personal Information Form', the'Daily Hassles Scale' and the 'Subjective Well Being (SWB).T-Tests were used to describe students' demographic characteristics by gender, ANOVA to describe the relationship between SWB and students' demographic and family characteristics, and Stepwise regression to describe how daily hassles predict subject well being. There was a significant relationship between students' pocket money and academic achievements and their subjective well-being; no relationship was observed between their gender, parents' income or educational level and the number of siblings they had and their SWB . Students' problems with family, educational life and their wider environment had a significant influence on their SWB. The results of the research were discussed in accordance with the relevant literature and the suggestions were offered.
\end{abstract}

Keywords: subjective well being, daily hassles, adolescence

\section{Introduction}

Eighth grade in the Turkish education is a phase that majorly influences a students'future. This is because at the end of eighth grade, a student undertakes a high school entrance exam and chooses a high school from among schools with different features. The type of high school a student will subsequently attend has a bearing on he university he or she will attend and his or her ensuing profession. Adolescence, the period of transition fromt childhood to adulthood, is a period of immense physical and emotional changes (Kulaksizoglu, 2004) that greatly influences adolescents' lives; they can enact negative behaviours like drug addiction, inconsistency in school attendance and exhibit behavioral disorders that impact their future roles and responsibilities (Eryılmaz \& Ögülmüss, 2010; Mcknight, Huebner \& Suldo, 2002). High school exams coincide with the onset of the adolescent period between 11 and 21 years,. Eighth grade students therefore undergo adolescence as they undertake vital eighth grade high school entry exams. In this critical period, understaing factors that influence 8th grade students' well-being, will provide information that can be used to ameliorate future failures (Ozguven, 2001).

According to Seligman (2002), negative emotions hinder individual development. Happiness is an important life ideal globally described as condition of a good life (Diener, Sapyta \& Suh, 1998). Happiness is addressed by the psychological concept of 'subjective well-being (SWB). Subjective well-being describes how an individual evaluates his or her life and expresses an opinion (Myers \& Deiner, 1995). If an individual has more life experiences of pleasure and fewer life experinces of displeasure, that individual has high levels of subjective well-being (Diener \& Diener, 1996; Eryllmaz, 2010).

Under focal theories, theories of need have a significant bearing on subjective well-being. The oldest preposition on which theories of need are based is the fact that an individual as a being tends to select pleasure and satisfaction by avoiding pain and sadness (Diener, 1984; Ryan \& Deci, 2001; Wilson, 1967). It is believed that when needs are addressed in a timely fashion, this brings happines, while persistently unfulfilled needs cause unhappiness (Wilson, 1967). This is especially so as regards to basic needs whose fullfilment promotes pleasure and happiness (Glasser, 2005).

Studies related to subjective well-being have been addressed by Köker (1991) and Nalbant (1993) in terms of life satisfaction; by Baker (1998) in terms of school satisfaction; by Suldo and Huebner (2006) in terms of teacher support; 
by Çevik (2010) and Şahin (2011) in terms of social support; by Cheng and Furnham (2002) in terms of academic achievement; by Çevik (2010), Yorulmaz and Eryılmaz (2006) in terms of self-esteem; by Eryılmaz and Öğülmüş (2010) and Yavuz (2006) in terms of personality traits; and by Çelik (2008) in terms of emotional intelligence.

Recent studies related to adolescent and child subjective well-being have focused on demographic factors (age, gender and socio-economic level etc.) and personal characteristics (the self-concept, extroversion, internal locus of control etc.) (Eryılmaz \& Öğülmüş, 2010). While McCullough, Huebner and Laughlin (2002) found that demographic factors' have a little bearing on adolescent subjective well-being., an individuals' subjective and versatile nature has an influence on subjective well-being. It is therefore necessary to assess subjective well-being on the basis of various concepts and characteristics related to an individual's nature (Özbay, Palancı, Kandemir \& Çakır, 2012).

Recently, educators and psychologists have redirected the focus on education and school studies to examining positive structures and improved skills and capacity, as opposed to pathology-weighted studies (Greenspoon \& Saklofske, 2001; Gilman \& Huebner, 2006; Suldo, Riley \& Shaffer, 2006). This tendency has led to an increase in studies related to positive psychology. 'Preventiveness' which is a concept of positive psychology, aims to anticipate and address problems before they arise and minimize risks associated with any future problems (Caplan, 1964). The 'Preventiveness Approach' is as a result of an interaction between an individual and his or her environment. 'Preventiveness' implies that an individual minimizes the effect of his or her environmental stress factors and improve his or her capacities to address them (Meyers \& Nastasi, 1999). Consequently, it is important to evaluate adolescents' daily hassles in order to reduce their risks and promote a healthy adaptation to them.

Adolescents'emotional experiences, peer relationships, peer acceptance, relationships with family and environment can affect their individual life satisfaction (Kaya \& Siyez, 2008). An individual has to solve a lifetime of real-life problems so as to obtain satisfaction from life and be happy (Dora, 2003). Students are under the influence of their family before they start the school after which they spend in large part of the day outside the home. School and other factors therefore begin having an influence on students' success (Çelenk, 2003). Therefore, it is crucial to assess a child's family environment where he or she grows as well as his or her social environment (Cüceloğlu, 1991).

Plenty of factors influence an individual's subjective well-being (Erylmaz, 2010). A good example of these are an individuals' daily hassles. Daily hassles are defined as situations experienced by an individual in daily life that cause stress and anger (Yıldırım, 2004). According to Lazarus (1984), students' daily hassles range from expereinces like continuing school studies, to fall, to school becoming boring etc. Such situations are commonly experienced by Eighth grade students as they prepare for high school entrance exams (Yıldırım, 2004). Research studies have shown that daily hassles, which are more predictive psychological symptoms than negative life events, are an important source of stress (Holahan \& Moos, 1987; Kanner, Coyne, Schaefer \& Lozarus, 1981). As they prepare for their exam, Turkish students experience various daily hassles related to their families, friends, schools, teachers, lessons, commuting to and from school, traffic and noise and this puts them through a difficult period (Yıldırım, 2006).

Although various studies related to adolescents have been conducted, limited attention has been paid to their subjective well-being. Research studies have not addressed the relationship between eighth grade students'daily hassles and their subjective well-being.

This study addresses the following research questions with a view to providing information to enhance students' subjective well being and providing baseline information on which future studies will be based:

- Do eighth grade students' subjective well-being vary with their gender, parents' educational level, parental income, number of siblings in their families, the amount of pocket money provided to them and their academic achievements?

- Are eighth grade students' daily hassles (hassles about family, friends, educational life and wide enviroment) associated with their subjective well-being?

\section{Methods}

\subsection{Study Population}

A relational screening model was used to describe the relationship between subjective well-being and various personal and family characteristics among eighth grade students .

The study sample was comprised of a total 408 eighth grade students (206 girls, 202 boys) of varying socio- economic statuses in four schools in Malatya in Turkey. After obtaining prerequisite authorization, participating schools were visited and study procedures explained.

\subsection{Data Collection Instruments}

Data was collected from students using a 'Personal Information Form' and two different scales i. e. "Daily Hassles Scale" and "Subjective Well-Being Scale". 


\subsubsection{The Personal Information Form}

This was used to collect demographic information that included gender, parents' educational level, income level, number of siblings, amount of pocket money provided, and students' academic achievements.

\subsubsection{The Daily Hassles Scale}

The Daily Hassles Scale (DHS) that was developed by yıldırım (2004) consists of four sub-scales namely; Hassles About Family (HAF) that consists of 14 items, Hassles About Friends (HAFR) that consists of 11 items, Hassles About Educational Life (HAEL) that consists of 20 items and Hassles About Wide Environment (HAWE) that consists of 7 items.

To validate the Daily Hassles Scale, the DHS was compared to the Beck Depression Inventory (BDI), Text Anxiety Inventory (TAI) and Percieved Social Support Scale (PSSS) using a group of 360 persons for Similiar Scales Validity. There was a direct relationship between the Daily Hassles Scale and its subscales BDI and TAI; and an indirect relationship between Daily Hassles Scale and the PSSS subscales.

The reliability of Daily Hassles Scale was analysed using the cronbach alpha reliability coefficient and the test-retest reliability method. Cronbach alpha was.91 for all of the DHS and.83 for HAF; .77 for HAFR; .83 for HAEL and .75 for HAWE. Test-retest correlation coefficients was. 93 for DHS.

\subsubsection{The Subjective Well-Being Scale}

The Subjective Well-Being Scale (SWBS) is a 37 item scale consisting of personal judgments regarding different areas of life that may have an effect on an individual's life satisfaction and positive and negative affect.

Studies of validity and reliability of SWBS forms developed by Tuzgöl Dost (2004) and Ozen (2005) have been done on high school students.

The reliability of the SWBS using cronbach alpha reliability coefficient was .91; and the pearson product moment correlation coefficient scored by the test-retest method was .82. This was therefore a reliable scale for adolescents.

Factor analysis was done to validate the SWBS form prepared for adolescents by Özen (2005) using that prepared for university students by Tuzgöl-Dost (2004); the coefficient of concordance was .85 . This indicates that factor structures of two groups were substantially similiar.

The SWB Scale's criterion validity was assessed using the Reynold Adolescent Depression Scale. The Spearman's Rho correlation Coefficient both scales was -.60 ( p<.01) (Özen, 2005). The internal consistency coefficient of the "Subjective Well-Being Scale" used in this study was found to be .90 .

\subsection{Data Collection}

Prerequisite explanations were made by the researcher to the student volunteers in classes on designated dates. The researcher explained the significance of the study with a view to encourage them to provide truthful responses and inform them not to indicate their names on the data collection tools. It took approximately 30 minutes to complete data collection.

\subsection{Data Analyses}

Participant characteristics were summarized using proportions and measures of central tendency. T-Test was used to determine the relationship bewtween SWB levels and gender.

ANOVA test was used to describe the association between SWB scores and parents' educational level, monthly income, number of siblings, amount of pocket money provided and students' academic achievements.

LSD (Least Significant Differance ) Post Hoc Test was used to compare amount of pocket money provided to to SWB. LSD Post HocTest was also used to examine the relationship between SWB levels and academic achievement status.

The Correlation relation between SWB and the following predictor variables was computed: HAF: Hassles About Family, HAFR: Hassles About Friends, HAEL: Hassles About Educational Life and HAWE: Hassles About Wide Environment.

Stepwise Regression analysis was used to assess how daily hassles predict subject well being.

Significance level was accepted as .05 in the study. Data was analysed using IBM SPSS 20 Pack Programme. 


\section{Results}

\subsection{Participant Characteristics}

Participants characteristics are summarize in Table 1

Table 1. Information about gender, educational status of parents, level of income, the number of sibling, the amount of pocket money and academic achievement status

\begin{tabular}{|c|c|c|c|}
\hline \multirow{3}{*}{ Gender } & & $\mathrm{N}$ & Frequency $\%$ \\
\hline & Girl & 206 & 50.5 \\
\hline & Boy & 202 & 49.5 \\
\hline \multirow{5}{*}{$\begin{array}{l}\text { Mother Education } \\
\text { Status }\end{array}$} & Primary School & 209 & 51.2 \\
\hline & Secondary School & 112 & 27.5 \\
\hline & High School & 41 & 10 \\
\hline & University & 10 & 2.5 \\
\hline & Other & 36 & 8.8 \\
\hline \multirow{5}{*}{$\begin{array}{l}\text { Father } \\
\text { Status }\end{array}$} & Primary School & 116 & 28.4 \\
\hline & Secondary School & 140 & 34.3 \\
\hline & High School & 106 & 26 \\
\hline & University & 35 & 8.6 \\
\hline & Other & 11 & 2.7 \\
\hline \multirow{4}{*}{$\begin{array}{l}\text { Family } \\
\text { Level }\end{array}$} & $0-850 \mathrm{TL}$ & 136 & 33.3 \\
\hline & $851-1600 \mathrm{TL}$ & 170 & 41.7 \\
\hline & $1601-2500 \mathrm{TL}$ & 59 & 14.5 \\
\hline & 2501 TL and more & 43 & 10.5 \\
\hline \multirow{4}{*}{$\begin{array}{l}\text { The Number of } \\
\text { Sibling }\end{array}$} & Having no sibling & 14 & 3.4 \\
\hline & Having one sibling & 70 & 17.2 \\
\hline & Having two sibling & 111 & 27.2 \\
\hline & Three and more & 213 & 52.2 \\
\hline \multirow{4}{*}{$\begin{array}{l}\text { The Amont of } \\
\text { Pocket Money }\end{array}$} & No pocket money & 36 & 8.8 \\
\hline & Less than $1 \mathrm{TL}$ & 79 & 19.4 \\
\hline & $1-2 \mathrm{TL}$ & 234 & 57.4 \\
\hline & More than $2 \mathrm{TL}$ & 59 & 14.5 \\
\hline \multirow{3}{*}{$\begin{array}{l}\text { The Academic } \\
\text { Achievement } \\
\text { Status }\end{array}$} & Failing $(<45)$ & 102 & 25 \\
\hline & $\begin{array}{l}\text { Passing the class without } \\
\text { bad mark (45-69) }\end{array}$ & 91 & 22.3 \\
\hline & $\begin{array}{lrl}\text { Taking certificate } & \text { of } \\
\text { achievement }(70-100)\end{array}$ & 215 & 52.7 \\
\hline
\end{tabular}

\subsection{Relationship Between Gender and SWB}

There was no significant relationship between eighth grade students 'SWB scores and their gender (Table 2).

Table 2. According to gender, t-test results of eighth grade students' SWB scores

\begin{tabular}{lcccccc}
\hline Variable & $\mathrm{N}$ & $\mathrm{M}$ & $\mathrm{sd}$ & $\mathrm{df}$ & $\mathrm{t}$ & $\mathrm{p}$ \\
\hline Girl & 206 & 142.67 & 24.35 & 406 & .96 & .33 \\
Boy & 202 & 140.52 & 20.36 & & & \\
\hline Total & 408 & & & & & \\
\hline
\end{tabular}

\subsection{Relationship Between Family Characteristics and SWB}

Students' SWB levels were significantly associated with the amount of pocket money provided and their academic achievement status. However, Eighth grade SWB scores did not vary significantly according with parents' educational level, number of sibling or monthly income level (Table 3). 
Table 3. According to demographic variables, ANOVA results of eight grade students' SWB scores

\begin{tabular}{|c|c|c|c|c|c|c|}
\hline & Total variance & Sum of squares & $\mathrm{df}$ & Mean squares & $\mathrm{F}$ & $\mathrm{p}$ \\
\hline \multirow{3}{*}{$\begin{array}{l}\text { Mother } \\
\text { Education } \\
\text { Status } \\
\end{array}$} & Inter grups & 1690.92 & 4 & 410.23 & & \\
\hline & Within grups & 203805.88 & 403 & 505.72 & .81 & .510 \\
\hline & Total & 205446.81 & 407 & & & \\
\hline \multirow{3}{*}{$\begin{array}{l}\text { Father } \\
\text { Education } \\
\text { Status } \\
\end{array}$} & Inter grups & 4555.01 & 4 & 1138.75 & & \\
\hline & Within grups & 200891.8 & 403 & 498.49 & 2.28 & .060 \\
\hline & Total & 205446.81 & 407 & & & \\
\hline \multirow{3}{*}{$\begin{array}{l}\text { Family Income } \\
\text { Level }\end{array}$} & Inter grups & 2435.07 & 4 & 608.75 & & \\
\hline & Within grups & 203011.8 & 403 & 503.75 & 1.20 & .30 \\
\hline & Total & 205446.81 & 407 & & & \\
\hline \multirow{3}{*}{$\begin{array}{l}\text { The Number of } \\
\text { Sibling }\end{array}$} & Inter grups & 2442.54 & 4 & 814.18 & & \\
\hline & Within grups & 203004.26 & 403 & 502.48 & 1.62 & .18 \\
\hline & Total & 205446.81 & 407 & & & \\
\hline \multirow{3}{*}{$\begin{array}{l}\text { The Amont of } \\
\text { Pocket Money }\end{array}$} & Inter grups & 5197.43 & 4 & 1299.36 & & \\
\hline & Within grups & 200249.37 & 403 & 496.89 & 2.61 & .035 \\
\hline & Total & 205446.81 & 407 & & & \\
\hline \multirow{3}{*}{$\begin{array}{l}\text { The Academic } \\
\text { Achievement } \\
\text { Status }\end{array}$} & Inter grups & 18817.31 & 2 & 9408.65 & & \\
\hline & Within grups & 186629.50 & 405 & 460.81 & 20.41 & .01 \\
\hline & Total & 205446.81 & 407 & & & \\
\hline
\end{tabular}

\subsection{Relationship Betweeen Students'Pocket Money and SWB}

Students' that received pocket money of between 1 and 2 Turkish liras (TL) and more than 2 Turkish liras, had higher SWB levels than students' who did not receive any pocket money (Table 4).

Table 4. Findings about LSD test related the difference between SWB scores and the amount of pocket money

\begin{tabular}{cccc}
\hline (I) The amont of pocket money & $(\mathrm{J})$ The amont of pocket money & Difference between the mean $(\mathrm{I}-\mathrm{J})$ & $\mathrm{p}$ \\
\hline 1-2 TL & No pocket money & 9.97 & .01 \\
More than 2 TL & No pocket money & 11.21 & .01 \\
\hline
\end{tabular}

\subsection{Relationship Between Students'Achievements and SWB}

Students' who held a certificate or higher level of academic achievement had SWB levels than students' who failed or passed the class with bad mark (Table 5).

Table 5. Findings about LSD test related the difference between SWB scores and academic achievement

\begin{tabular}{cccr}
\hline (I) The academic achievement status & $(\mathrm{J})$ The academic achievement status & Difference between the mean (I-J) & $\mathrm{p}$ \\
\hline Taking certificate of achievement & Failing & 15.69 & .01 \\
\hline Taking certificate of achievement & Passing the class without bad mark & 10.06 & .01 \\
\hline
\end{tabular}

3.6 Correlations Between DHS Predictor Variables and SWB

The correlation between HAF and SWB was $(r=-.60, \mathrm{p}<.01)$, between HAFR and SWB was $(\mathrm{r}=-.38$, $\mathrm{p}<.01)$, between HAEL and SWB was $(r=-.50, \mathrm{p}<.01)$, and between HAWE and SWB was $(r=-.40, \mathrm{p}<.01)$.

Table 6. Correlation values between SWB, HAF, HAFR, HAEL and HAWE variables

\begin{tabular}{lccccr}
\hline Variable & $\mathbf{1}$ & $\mathbf{2}$ & $\mathbf{3}$ & $\mathbf{4}$ & $\mathbf{5}$ \\
\hline (1) Subjective Well-Being & 1 & & & & \\
(2) Hassles About Family & $-.608^{* *}$ & 1 & & & \\
(3) Hassles About Friends & $-.385^{* *}$ & $.485^{* *}$ & 1 & & \\
(4) Hassles About Education Life & $-.500^{* *}$ & $.534^{* *}$ & $.503^{* *}$ & 1 & \\
(5) Hassles About Wide Environment & $-.408^{* *}$ & $.462^{* *}$ & $.380^{* *}$ & $.499^{* *}$ & 1 \\
\hline
\end{tabular}

SWB: Subjective Well-Being HAF: Hassles About Family HAFR: Hassles About Friends

HAEL: Hassles About Educational Life HAWE: Hassles About Wide Environment 


\subsection{Predictor Variables for $S W B$}

Table 7. Stepwise regression analysis related Daily Hassles as a predictor of SWB

\begin{tabular}{|c|c|c|c|c|}
\hline & $\mathrm{B}$ & Std. Error & $\beta$ & $\mathrm{R}^{2}$ \\
\hline \multicolumn{5}{|l|}{ 1. $\quad$ Step } \\
\hline (Costant) & 192.826 & 3.434 & & \\
\hline HAF & -2.410 & .156 & $-.608 *$ & .370 \\
\hline \multicolumn{5}{|l|}{ 2. $\quad$ Step } \\
\hline (Costant) & 204.785 & 3.979 & & \\
\hline HAF & -1.891 & .178 & $-.477 *$ & \\
\hline HAEL & -.692 & .127 & $-.245^{*}$ & .410 \\
\hline \multicolumn{5}{|l|}{ 3. $\quad$ Step } \\
\hline (Costant) & 208.037 & 4.269 & & \\
\hline HAF & -1.790 & .184 & $-.452 *$ & \\
\hline HAEL & -.599 & .183 & $-.213^{*}$ & \\
\hline HAWE & -.714 & .348 & $-.093 *$ & .419 \\
\hline
\end{tabular}

Note: $\mathrm{N}=408, * \mathrm{p}<.01, \quad \mathrm{R}^{2}=.370$ for first step, $\mathrm{p}=.01$; the differentiation in $\mathrm{R}^{2}$ for second $\mathrm{ste}=4, \mathrm{p}=.01$; the differentiation in $\mathrm{R}^{2}$ for third step $=.09, \mathrm{p}=.01$, total $\mathrm{R}^{2}=.419$

In the 1st step of the Hierarchical Regression analysis, HAF had a Standardized Regression Coefficient ( Beta) of -0.608 in predicting 8th Grade students SWB. This means that HAF alone predicted $37 \%$ of SWB $\left(R=0.608, R^{2}=0.370\right.$, $\mathrm{p}=0.01$ ).

In the 2nd step of the Hierarchical Regression Analysis HAF and HAEL were included in the model; HAF and HAEL predicted $41 \%$ of students SWB $\left(\mathrm{R}=0.608, \mathrm{R}^{2}=0.370, \mathrm{p}=0.01\right)$.

In the 3rd step of the Hierarchical Regression Analysis HAF, HAEL and HAWE were included in the model; HAF, HAEL and HAWE predicted $42 \%$ of students' $\mathrm{SWB}\left(\mathrm{R}=0.647, \mathrm{R}^{2}=0.419, \mathrm{p}=0.01\right)$ of $\mathrm{SWB}$

An other acquired finding is that HAFR sub-dimension scores' benefit to the model is not significant statistically (p>.05).

\section{Discussion}

Research findings indicated that HAF, HAEL and HAWE had a signficant inverse relationship with SWB; they predicted $42 \%$ of SWB. Additionally, although gender, educational status of parents, family income level, the number of siblings did not signficantly influence SWB; there was a significant relation between the amount of pocket money provided and a student's academic achievement with SWB.

The SWB of eighth grade students in Turkey did not vary with gender similar to published literature (Ben-Zur, 2003; Çevik, 2010; Diener, 1984; Diener, Such, Lucas \& Smith, 1999; Eken, 2010; Kartal, 2013; Katja, Paiva, Marja, Terttu \& Pekka, 2002; Mahon, Yarcheski \& Yarcheski, 2005; Nigar, 2014; Özen, 2005; Tuzgöl-Dost, 2004; Tuzgöl-Dost, 2006). This could be attributed to developmental characteristics of schoolgirls and boys in this agegroup (Çelik, 2008). High school transfer exams causes anxiety in both girls and boys since exam results will determine whether or not they are accepted at academic or vocational high schools. However, conflicting results have been observed in some studies(Çivitçi, 2009; Doğan \& Yıldırım 2006; Tuzgöl-Dost, 2007; Sezer, 2011).

The parents' educational level had no influence on the SWB of eighth grade students as has been observed by Eken (2010) and Şahin (2011). Parental communication, love and care supersede their level of education and the parental-child relationship has an enourmous bearing on SWB. Trained parents will therefore enhance their children's SWB. Nevertheless, limited information exists as regards the relationship between SWB and parental level of education.

Family income had no influence on students' SWB. Howerver, in the literature family income has been shown to have an influence on SWB (Canbay, 2010; Kermen, 2013; Özen, 2005; Tuzgöl-Dost, 2006; Tuzgöl-Dost 2010)and also not to have an influence on SWB (Şahin, 2011; Şahin \& Karabeyoğlu, 2010; Topuz, 2013). Children from families with lower monthly incomes have been observed to be happier than those from families with higher monthly incomes(Şahin, 2011) This maybe because this may not be their source of happiness. It is debatable whether more money brings happiness or not (Dienher, Such, Lucas \& Smith, 1999).

İn this study, SWB scores did not vary with the number of siblings, as observed by Eken (2010) and Sahin (2011) (Eken, 2010; Şahin, 2011);nevertheless, Kartal (2013) found a relationship between SWB and the number of siblings (Kartal, 2013). Siblings provide social support, promote cooperation and this may result in decreased possibilities, disagreements and having more responsibilities. Although older siblings can provide support and care, they can be domineering and restrictive. The quality of relationships with one's siblings is more important than the number of 
siblings and this maybe why it is difficult to predict SWB using a student's number of siblings.

The amount of daily pocket money had a signficant influence on a students's SWB. The higher the pocket money, the higher the SWB. This maybe because a student with pocket momey, fulfls his or her needs and thus he or she gets satisfaction. Additionally, as individuals fulfill their emotional, social and physiological needs, they are in interaction with others and may compare themselves with other people (Erözkan, 2011). Observations among pubertal students have shown that student without pocket money may prefer to remain in the background, while students with pocket money may feel comfortable interacting with others. Limited information exists in the literature regarding the relationship between SWB and the amount of pocket money received.

SWB scores varied significantly with students'academic achievements. Overachieving students have higher SWB scores than underachieving students similar to published literature (Canbay, 2010; Tuzgöl-Dost, 2004; Özen, 2005). This is an expected situation because at this time school is the centre of the students' lives. Families at home, societal acquaintances, and school teachers all encourage and applaud excellent academic achievements. Students are therefore under a lot of pressure to be successful. This it is expected that students who perform well academically feel better about themselves.

There was a negative relationship between daily hassles and SWB; as daily hassles decrease, SWB increases. However, only HAF, HAEL and HAWE sub-dimensions of daily hassles had a signficant influence on SWB. As regards HAF, SWB begins with fulfilling basic needs which are provided for by family. Family support has been shown to positively influence SWB (Çevik,2010; Rask, Kurki \& Paavlianien, 2002). Karatzias, Chouliara, Power and Swanson (2006) illustrated that family relationship had an influence on SWB. Individuals who grow up in families with democratic attitudes, have higher SWB (Canbay, 2010; Şahin, 2011; Tuzgöl-Dost, 2004; Youngmiller, Norton \& Hill, 1995). They also acquire positive skills in self-expression, independent decision-making and self-esteem (Tuzglö-Dost, 2004). As regards HAEL, school is an important part of an adolescents'life. Education is a period of individual physical, emotional and social growth that an individual acquires skills to better both themselves and their society (Yeşilyaprak, 2006). According to Pitman (1992), schools and teachers provide students with opportunities to positively develop self-acceptance and self-control, self-reliance, relationships with the school and to improve their competencies. Children that feel respected, unique and important in school, will reflect these feelings to those around them and will communicate better with others (Sar1, 2007). There is a need to further investigate the influence of school on SWB because students' school difficulties can affect family and social life. As regards HAWE, there is a need to assess the social development of an adolescent. The world of the child is his or her own immediate environment which rapidly develops in puberty. With this development, adolescents begin to consider themselves to be part of whole community they live in, not just as part of their immediate environment of family, school and friends (Dereboy, 1993). Peer relationships, peer acceptance, family relationships and the immediate environment all have a determinative role on an adolescents' emotional life, prejudgments and social attraction. This can affect the individual's life satisfaction (Kaya \& Siyez, 2008) which in turn impacts an individual's SWB. Being socially active, experiencing positive emotions (Tuzgöl-Dost, 2005) and increasing social support have been shown to increase SWB (Şahin, 2011).

This study's strength stems from its comparison of daily hassles to SWB. The study recommends, SWB seminars for families at schools for them to better understand the effects of supporting their own children, informing teachers about the effect of children's educational life on their SWB and programs to increase students'SWB levels. Further research is recommended to examine the interaction between SWB and daily hassles and other factors, to explore the relationship between pocket money and SWB in a qualitative study, and to include students from different school types, educational levels, and social and cultural groups.

\section{References}

Baker, J. A. (1998). The social context of school satisfaction among urban, low-income, African-American students. School Psychology Quarterly, 13, 25-44. https://doi.org/10.1037/h0088970

Ben-Zur, H. (2003). Happy adolescents: The link between subjective well- being, internal resources and parental Factors, Journal of Youth and Adolescence, 32(2), 67-79. https://doi.org/10.1023/A:1021864432505

Canbay, H. (2010). The assessment of the relationship between the levels of subjective well-being and the the levels of social skills of the high school students, Unpublished PhD Thesis. Dokuz Eylul University, Izmir.

Caplan, G. (1964). Principles of preventive psychiatry. Oxford, England: Basic Books.

Çelenk, S. (2003). The prerequisite for school success: Home-school cooperation. Ilkogretim-Online, 2(2), 28-34.

Çelik, Ş. (2008). The investigation of the subjective well being of the high school students in terms of emotional intelligence, Unpublished Master Thesis. Selcuk University, Konya. 
Çevik, N. (2010). Some variables predicting high school studets subjective well being, Unpublished Master Thesis. Gazi University, Ankara.

Cheng, H., \& Furnham, A. (2002). Personality, peer relations, and selfconfidence as predictors of happiness and loneliness. Journal of Adolescence, 25, 327-339. https://doi.org/10.1006/jado.2002.0475

Çivitci, A. (2009). İlköğretim öğrencilerinde yaşam doyumu: Bazı kişisel ve ailesel özelliklerin rolü. Uludağ Üniversitesi Ĕ̈itim Fakültesi Dergisi, 22(1), 29-52.

Cuceloglu, D. (1991). İçimizdeki çocuk. İstanbul: Remzi kitabevi.

Dereboy, İ. F. (1993). Kimlik bocalaması, anlamak, tanımak, ele almak. Malatya: Özmert ofset.

Diener, E. (1984). Subjective well-being. Psychological Bulletin, 95, 542-575. https://doi.org/10.1037/0033-2909.95.3.542

Diener, E., \& Diener, C. (1996). Most people are happy. Psychological Science, 7, 181-185. https://doi.org/10.1111/j.1467-9280.1996.tb00354.x

Diener, E., Sapyta, J. J., \& Suh, E. (1998). Subjective well-being is essential to well-being. Pscyhological Inquiry, 9(1), 33-37. https://doi.org/10.1207/s15327965pli0901_3

Diener, E., Suh, E. M., Lucas, R. E., \& Smith, H. L. (1999). Subjective well-being: Three decades of progress. Psychological bulletin, 125(2), 276. https://doi.org/10.1037/0033-2909.125.2.276

Dogan, T., \& Y1ldırım, I. (2006). Investigation of the "Friendship" and "Love" subscales of wellness of university students, Eurasian Journal of Educational, s(24), 77-86.

Dora, S. (2003). Adaptation of the social problem solving inventory (revisied form): Its validity and reliability, Unpublished Master Thesis. Haccettepe University, Ankara.

Eken, A. (2010). The relationships between adolescents? types of attachment to parents, and their subjective well being and expectations for social self-efficacy, Unpublished Master Thesis. Karadeniz Teknik University, Trabzon.

Erözkan, A. (2011). Lise öğrencilerinin sosyal karşılaştırma ve depresyon düzeylerinin bazı değişkenlere göre incelenmesi. Sosyal Bilimler Enstitüsü Dergisi, 1(13).

Eryılmaz, A. (2010). The relationship between using of subjective well being increasing strategies and academic motivation in adolescence. Klinik Psikiyatri, 13, 77-84.

Eryılmaz, A., \& Ögülmüş, S. (2010). Subjective well-being and big five personality model at adolescence. Ahi Evran University Ĕgitim Fakültesi Dergisi, 11(3), 189-203.

Gilman, R., \& Huebner, E. S. (2006). Characteristics of adolescents who report very high life satisfaction. Journal of Youth and Adolescence, 35(3), 311-319. https://doi.org/10.1007/s10964-006-9036-7

Glasser, W. (2005). Kişisel özgürlüğ̈̈n psikolojisi: Seçim teorisi (Çev. M. İzmirli). İstanbul: Hayat yayınc1lık.

Greenspoon, P. J., \& Saklofske, D. H. (2001). Toward an integration of subjective well-being and psychopathology. Social Indicators Research, 54(1), 81-108. https://doi.org/10.1023/A:1007219227883

Holahan, C. J., \& Moos, R. H. (1987). Risk, resistance, and psychological distress: A longitudinal analysis with adults and children. Journal of Abnormal Psychology, 96, 3-13. https://doi.org/10.1037/0021-843X.96.1.3

Kanner, A. D., Coyne, J. C., Schaefer, C., \& Lazarus, R. S. (1981). Comparison of two modes of stress measurement: Daily hassles and uplifts versus major life events. Journal of Behavioral Medicine, 4(1), 1-39. https://doi.org/10.1007/BF00844845

Karatzias, A., Chouliara, Z., Power, K., \& Swanson, V. (2006). Predicting general well- being from self-esteem and affectivity: An exploratory study with scottish adolescents. Quality of Life Research, 15, 1143-1151. https://doi.org/10.1007/s11136-006-0064-2

Kartal, M. A. (2013). Subjective well-being and communication skill levels of secondary school students in some variables, Unpublished Master Thesis. Ondokuz Mayis University, Samsun.

Katja, R., Paiva, A. K., Marja-Terttu, T., \& Pekka, L. (2002). Relationships among adolescent subjective well-being,health behavior and school satisfaction, Journal of School Health, 72(6), 243-249. https://doi.org/10.1111/j.1746-1561.2002.tb07337.x

Kaya, A., \& Siyez, D. M. (2008). Sociometric status and life satisfaction in Turkish primary and secondary school students. Eurasian Journal of Educational Research, 32, 69-82. 
Kermen, U. (2013). The analysis of the concept of need satisfaction level and subjective well-being level on university students, Unpublished Master Thesis. Abant İzzet Baysal University, Bolu.

Köker, S. (1991). Normal ve sorunlu ergenlerin yaşam doyumu düzeyinin karşılaşttrılması, Unpublished Master Thesis. Ankara University, Ankara.

Kulaksizoglu, A. (2004). Ergen Psikolojisi. İstanbul: Remzi kitapevi.

Lazarus, R. S. (1984). On the primacy of cognition. American Psychologist, 39, 124-129. https://doi.org/10.1037/0003-066X.39.2.124

Mahon, N. E., Yarcheski, A., \& Yarcheski, T. J. (2005). Happiness as related to gender and health gin early adolescents, Clinical Nursing Research, 14(2), 175-190. https://doi.org/10.1177/1054773804271936

McCullough, G., Huebner, S., \& Laughlin, J. E. (2002). Life events, self concept, and adolescent's positive subjective well-being. Psychology in the School, 3, 281-290.

Mcknight, C. G., Huebner, E. S., \& Suldo, S. (2002). Relationships among stressful life events, temperament, problem behaviour, and global life satisfaction in adolescents, Psychology in the School, 39, 677-687. https://doi.org/10.1002/pits.10062

Meyers, J., \& Nastasi, B. K. (1999). Primary prevention in school settings. The handbook of school psychology, 3, 764-799.

Myers, D., \& Deiner, E. (1995). Who is happy. American Psychological Society. 6(1), 1-19. https://doi.org/10.1111/j.1467-9280.1995.tb00298.x

Nalbant, A. (1993). 15-22 yaşları arasında bulunan ıslahevindeki, gözetim altındaki ve suç işlememiş gençlerin benlik saygısı ve yaşam doyumu düzeylerinin karşılaştırllması, Unpublished Master Thesis. Ankara University, Ankara.

Nigar, F. (2014). Comparison with secondary school students -boarding secondary school students' subjective well-being and basic psychological needs level, Unpublished Master Thesis. Gazi Osman Paşa University, Tokat.

Özbay, Y., Palanc1, M., Kandemir, M., \& Çakır, O. (2012). Üniversite öğrencilerinin öznel iyi oluşlarının duygusal düzenleme, mizah, sosyal öz-yeterlik ve başa çıkma davranışları ile yordanması. Türk Eğitim Bilimleri Dergisi, 325.

Özen, O. (2005). Subjective well-being of adolescents, Unpublished Master Thesis. Haccettepe University, Ankara.

Ozguven, E. I. (2001). Ailede iletişim ve yaşam. Ankara: Pdrem yayınları.

Pittman, K. J. (1992). Defining the fourth R: Promoting youth development. Center for youth development. Washington, DC: Academy for educational development

Rask, K., Astedt-Kurki, P., \& Laippala, P. (2002). Adolescent subjective well-being and realized values. Journal of advanced nursing, 38(3), 254-263. https://doi.org/10.1046/j.1365-2648.2002.02175.x

Ryan, R. M., \& Deci, E. L. (2001). To be happy or to be self-fulfilled: A review of research on hedonic and eudaimonic well-being. Annual Review of Psychology, 52, 141-166. https://doi.org/10.1146/annurev.psych.52.1.141

Şahin, H., \& Karabeyoglu, A. Y. (2010). Well-being of university students who have lived abroad: The case of Hacettepe university. Eurasian Journal of Educational Research, 40, 171-187.

Şahin, N. G. (2011). Comparison of levels pertain to self disclosure, subjective well-being and perceived social support of university students, Unpublished Master Thesis. Dokuz Eylül University, Izmir.

Sari, M. (2007). The Effect of hidden curriculum on gaining democratic values: a qualitative study in two elemantary schools having low and high quality of school life, $\mathrm{PhD}$ Thesis. Çukurova University, Adana.

Seligman, M. (2002). Authentic happiness: Using the new positive psychology to realize your potential your potential for lasting fulfillment. New York, NY: Free press.

Sezer, F. (2011). The analysis of subjectıve well-being of secondry school students' in terms of some variables, Milli Ë̆itim Dergisi, 192, 74-85.

Suldo S., M., \& Huebner, E. S. (2006). Is extremely high life satisfaction during adolescence advantageous?. Social Indicators Research, 78, 179-203. https://doi.org/10.1007/s11205-005-8208-2

Suldo, S., M., Riley, K., \& Shaffer, E. S. (2006). Academic correlates of children and adolescents' life satisfaction. School Psychology International, 27, 567- 582. https://doi.org/10.1177/0143034306073411

Topuz, C. (2013). The relationship of altruism with subjective and psychological well-being among university students, 
Unpublished Master Thesis. Fatih University, İstanbul.

Tuzgol-Dost, M. (2004). Subjective well-being levels of university students. PhD Thesis, Haccettepe University, Ankara.

Tuzgol-Dost, M. (2005). Öznel iyi oluş ölçeği’nin geliştirilmesi: Geçerlik güvenirlik çalışması. Türk Psikolojik Danısma ve Rehberlik Dergisi, 3(23), 103-110.

Tuzgol-Dost, M. (2006). Subjective well-being among university students. Hacettepe University Eğitim Fakültesi Dergisi, 31, 188-197.

Tuzgöl-Dost, M. (2007). Examining life satisfaction levels of university students in terms of some variables. Pamukkale University Ĕgitim Fakültesi Dergisi, 22(2), 132-142.

Tuzgol-Dost, M. (2010). An examination of subjective well-being and life satisfaction of students attending to universities in South Africa and Turkey. Education and Science, 35(158), 75-89.

Wilson, W. (1967). Correlates of avowed happiness. Psychological Bulletin, 67, 294-306. https://doi.org/10.1037/h0024431

Yavuz, Ç. (2006). Subjective well being, psychiatric symptoms and personal characteristics of guidance and psychological counseling students: A comparative study, Unpublished Master Thesis, İstanbul University, İstanbul.

Yesilyaprak, B. (2006). Eğitimde rehberlik hizmetleri (14. Baskı). Ankara: Nobel yayınları

Yıldırım, I. (2004). Test anxiety, daily hassles, and social support as predictors of depression. Hacettepe University Ĕ̈itim Fakültesi Dergisi, 27, 241-250.

Yıldırım, I. (2006). Daily hassles and social support as predictors of academic achievement. Hacettepe University Eğitim Fakültesi Dergisi, 30, 258-267.

Yorulmaz, A., \& Eryllmaz, A. (2006). Examining the Relationship Between Adolescent Being Well, Self Esteem and Optimistic Tencency. Ulusal 14. Psikoloji Kongresi, Hacettepe University, Ankara, Türkiye, 6-8 Eylül.

Young, M. H., Miller, B. C., Norton, M. C., \& Hill, E. J. (1995). The effect of parental supportive behaviors on life satisfaction of adolescent offspring. Journal of Marriage and the Family, 813-822. https://doi.org/10.2307/353934

\section{Copyrights}

Copyright for this article is retained by the author(s), with first publication rights granted to the journal.

This is an open-access article distributed under the terms and conditions of the Creative Commons Attribution license which permits unrestricted use, distribution, and reproduction in any medium, provided the original work is properly cited. 